$\left.\begin{array}{c}\text { INTERNATIONAL JOURNAL OF } \\ \text { ORGANIZATIONAL LEADERSHIP }\end{array}\right) \begin{gathered}\text { INDUSTRIAL } \\ \text { MANAGEMENT } \\ \text { INSTITUTE }\end{gathered}$

\title{
Improving human resources management using the EFQM Excellence Model
}

\author{
Miriam Garbarova \\ ${ }^{1}$ Assistant Professor, Department of Communications, Faculty of Operation and Economics of Transport and \\ Communications, University of Zilina, Slovakia
}

\begin{abstract}
Keywords:

Human Resources,

EFQM, Business

Excellence, Results

Received

12 October 2016

Received in revised form

14 May 2017

Accepted

17 May 2017

Correspondence:

miriam.garbarova@fpedas.uniza

Success is fundamental to every organization and that is why organizations try to be successful. Organizations need unique business ideas and sufficient capital to be successful but no organization can exist without human resources. Therefore, employees are the main source of organizations' success. The aim of the current paper is to highlight the benefits of the EFQM Excellence Model as a tool that helps to improve human resource management. To fulfill the aim of the paper, the secondary research based on the methods of analysis, comparison, and selection is performed. Case studies focused on organizations that improved their human resources management using the EFQM Excellence Model are used as the main sources of the secondary research. As a result, the secondary research provided a finding that the EFQM Excellence Model may be considered as a tool that helps to improve human resource management. Recommendation arising from the paper is to use the EFQM Excellence Model for improving organizations’ results including results towards employees.
\end{abstract} .sk

(C)AIMI Journals

Success has different meanings for different organizations; moreover, it has multiple explanations. The vagueness of success and failure resulted in great deal of theories about achieving the excellence in companies, projects, and even in activities (Vartiak, 2015). Different people look at their success differently but there is something that is common in the different definitions of success and it is called human resources. In the human services areas of various businesses and in the educational and political fields, some valid explanations for the success has been provided and all of them include human resources (Konrad, Prasad, \& Pringle, 2006). Thus, human resources are regarded as the significant assets of every 
organization. An importance of human resources in organizations is great because they organize, design, apply, sustain, and end an organization's life. Following this, management of human resources is considered as one of the most important functions in an organization (Senyucel, 2009).

The aim of the paper is to highlight the benefits of the EFQM Excellence Model as a tool that helps to improve human resource management. The paper consists of four parts: An input to the problem and theoretical background are included in introduction. Methodology describes paper's creation process and methods used to fulfill the aim of the paper. Results' part comprises secondary research that consists of analyzing the case studies focused on the improvement of human resources management by using the EFQM Excellence Model. The last part - conclusion - evaluates the results of secondary research.

\section{The Literature Review}

The term human resources is composed of all the efforts, skills or capabilities of all the people who work for the organization. There is no difference between human resources, staff, workforce, personnel or employees, when it comes to defining people that work for an organization. On the other hand, executives of an organization are supposed to manage its human resources in the most effective manner so they work well in the best interests of the organization; in actual fact, human resources work in their own interests, too (Joshi, 2013).

It is important to note that human resources are contextual. What an organization needs from its human resources that is being delivered differ from place to place. The role of human resources is influenced by the particular industry, unique business challenges, and organizational history and its capabilities (Reucroft \& Scott, 2015).

Therefore, human resources are managed in every organization. Human resources management is the management of the people and the staff policies and practices that enable an organization to carry out its work. This affects human resources from the moment an individual contacts the organization in response to a job advertisement, to the time they leave the organization. Good human resources management is essential if organizations want to attract and retain good staff (ATG Educational, 2008).

Human resources management, as well as other functional areas of management, is under the intense pressure of globalization while this irreversible development brings both positive and negative consequences (Ponisciakova \& Gogolova, 2015). Organizations, however, have abandoned the traditional way of thinking about work and people. Employment is nowadays more than just having a job - it is a combination of responsibilities and duties represented by the relationship between the organization and the employees (Senyucel, 2009).

To this end, the goal is to maintain good relations between organizations and human resources by adopting new management approaches that help to improve human resources. Fulfillment of such goal can be supported by many management frameworks. These frameworks are oriented on quality or on finances (Vartiak, 2016). As demonstrated by other researches (Jankalova, 2001; Vouzas, Gotzamani, \& Ispikoudi, 2007; Misiakova \& Strenitzerova, 2011; Jamshid, Mahsa \& Hasan, 2014; Mashinchi \& Jahanian, 2015), one of the best-known management approaches in Europe that can be used for improving human resources management is the EFQM Excellence Model. 
The EFQM Excellence Model is a business excellence model which is applicable for looking at organizational excellence, as well as excellence in the field of human resources management. An important reason for the major revision of the model in 2010 was the recognition of strong trends of innovation, risk management, and sustainability (Samardzija \& Kralj, 2010).

Another revision of the EFQM Excellence Model in 2012 confirmed that not only quality is an important issue but even internal and external stakeholders have found their place in the model. Criteria of the EFQM Excellence Model are divided into two parts, namely enablers and results. Enablers are: leadership; people; strategy; partnerships \& resources; processes, products \& services. Results consist of these four criteria: people results; customer results; society results; business results (European Foundation for Quality Management, 2012).

\section{Method}

The aim of the paper is to highlight the benefits of the EFQM Excellence Model as a tool that helps to improve human resource management. To fulfill the aim of the paper, the secondary research based on the methods of analysis, comparison, and selection is performed.

Case studies focused on organizations that improved their human resources management using the EFQM Excellence Model are used as the main sources of the secondary research. Analyzed case studies were published by the European Quality Assurance in Vocational Education and Training (EQAVET). According to its official website (European Quality Assurance in Vocational Education and Training, n.d.-a), EQAVET is a community of practice bringing together member states, social partners, and the European commission to promote European collaboration in developing and improving quality assurance by using the EFQM Excellence Model. These European countries, namely Cyprus, Czech Republic, Estonia, Hungary, Italy, Slovenia, and United Kingdom were included in analyzed case studies published by EQAVET.

\section{Results}

The Intercollege in Nicosia, Cyprus uses the EFQM Excellence Model to conduct an annual self-assessment which starts with a workshop for the management team assessing evidence and date in order to identify strengths and weaknesses. This is followed by decisions on improvements that need to be made, allocating responsibilities for implementation and agreeing a timescale for improvements. The ongoing annual self-assessment has led to improvements in the quality of relations between employees which is fundamental for achieving the higher quality of work (European Quality Assurance in Vocational Education and Training, n.d.-b).

The Secondary Technical and Vocational Building School which is situated in Kolin, Czech Republic, has introduced major changes in its management structures. Such changes are focused on the establishment of better cooperation with its external partners. This is supported by greater internal cooperation between employees (teachers and trainers) through meetings of subject boards. These arrangements have been introduced to enable greater flexibility and such developments have led to a ten per cent increase in applicants (European Quality Assurance in Vocational Education and Training, n.d.-c). 
EFQM Excellence Model is a very helpful tool for the Tartu Vocational Education Centre situated in Estonia. The Centre uses it for yearly self-assessment of teachers, management members, and external stakeholders. Quality assurance and planning of development has been actively promoted by the Centre. The management team set out to involve staff and students in creating a shared organization culture within a modern learning environment. The main challenge has been to enable all staff to understand that quality assurance is not an external obligation. Rather it is relevant tool for ensuring development, competitiveness, and satisfaction of all stakeholders. Nowadays, the Centre is well-known for its success in organization learning (European Quality Assurance in Vocational Education and Training, n.d.d).

Hungarian school named the Ferenc Hansagi School for Catering and Tourism, which is situated in Szeged, has been noting every requirement from its stakeholders and assessing them since 2000. As part of the school's annual plan, views are collected from employees, students, and the school's supporting foundation and organizations that provide apprenticeship places. The school is well-known for the use of action plans. In addition, using partner satisfaction measurements to inform self-evaluation and self-assessment has ensured the school and its managers stay focused on the needs of employers. However, to make this quality system work, there needs to be an effective approach to internal communications which is based on the commitment and willingness of all the staff (European Quality Assurance in Vocational Education and Training, n.d.-e).

CIOFS-FP, a non-profit association which operates in 14 regions in Italy through 70 local centers, has adopted self-assessment procedures developed by EFQM. It has led to a standardized approach to internal procedures, business processes, defining tasks and responsibilities and analyzing performance by management and the human resources department. By the use of this methodology, strengths of the Association can be highlighted. The increasing importance of involving the human resources team in the Association has resulted in supporting continuous improvement of the quality management system by the full involvement of the human resources in achieving the goals of the Association. Also, internal communications have been improved (European Quality Assurance in Vocational Education and Training, n.d.-f).

A publicly-funded center situated in Nova Gorica, Slovenia, named TSC, has established a quality assurance committee. Alongside the regular collection of feedback, the school has adopted the EFQM Excellence Model and has participated in various quality assurance projects which support employees and develop the school's approach to quality assurance. From each project an evaluation has provided clear feedback that there is a need for constant improvement and the involvement of all employees. This need has been recognized and internal communications, as well as relations between employees has been improved (European Quality Assurance in Vocational Education and Training, n.d.-g).

In the United Kingdom, there is one of the biggest suppliers of meat products named Dunbia. It declares an emphasis on training and developing high quality and that is why it is successful. It has been certified as an assessment center and this regular training is based on the EFQM Excellence Model. It shows how employees' needs can be included in the qualification development process and how their support program can be used to improve employees' skills 
and to make sure that they are satisfied. It also promotes organizations' involvement in qualification design (European Quality Assurance in Vocational Education and Training, n.d.h).

\section{Discussion and Conclusion}

Nowadays, when situation in global financial markets is unstable and competitive pressure is too strong, the only success factors which organizations can rely on are human resources; however, it is necessary to develop human resources. For this purpose, there are a number of management tools. As already mentioned, many research have confirmed that the EFQM Excellence Model is one of the best-known management approaches in Europe which can be used for improving human resources management. The aim of the paper was to highlight the benefits of the EFQM Excellence Model as a tool that helps to improve human resource management. To fulfill the aim of the paper, the secondary research, consisting of case studies focused on organizations that improved their human resources management using the EFQM Excellence Model was performed. Analyzed case studies, published by EQAVET, were located in European countries, namely Cyprus, Czech Republic, Estonia, Hungary, Italy, Slovenia, and United Kingdom. As a result, the secondary research provided a finding that the EFQM Excellence Model was considered as a tool that helps to improve human resource management in the areas such as improvements in the quality of relations between employees, achievement of the higher quality of work, greater internal cooperation between employees, creating a shared organization culture, in the areas that managers stay focused on the needs of employers, effective internal communications, and the full involvement of the human resources in achieving the goals of an organization.

To summarize, using of the EFQM Excellence Model can ensure development, competitiveness, and satisfaction of employees. Therefore, the EFQM Excellence Model is not only a business excellence model but it can also be considered as a model for managing human resources. Recommendation arising from the results of the secondary research is to use the EFQM Excellence Model for improving organizations' results including results towards employees. 


\section{References}

ATG Educational. (2008). Human resources management. London: ATG Educational.

European Foundation for Quality Management. (2012). An Overview of the EFQM Excellence Model. Brussels: EFQM.

European Quality Assurance in Vocational Education and Training (n.d.-a). Welcome to EQAVET. Retrieved from http://www.eqavet.eu/gns/home.aspx

European Quality Assurance in Vocational Education and Training (n.d.-b). Cyprus - self-assessment. Retrieved from http://www.eqavet.eu/qc/gns/case-studies/2008-Case-Studies/cyprus-self-assessment.aspx

European Quality Assurance in Vocational Education and Training (n.d.-c). Czech Republic - Involving internal and external stakeholders. Retrieved fromhttp://www.eqavet.eu/qc/gns/case-studies/2008-Case-Studies/czech-internal-and-externalstakeholders.aspx

European Quality Assurance in Vocational Education and Training (n.d.-d). Estonia - A Five Year Development Plan. Retrieved from http://www.eqavet.eu/qc/gns/case-studies/2008-Case-Studies/estonia-five-year-development-plan.aspx

European Quality Assurance in Vocational Education and Training (n.d.-e). Hungary - Using feedback from partners to improve VET. Retrieved from http:/www.eqavet.eu/qc/gns/case-studies/2008-Case-Studies/hungary-feedback-frompartners-improve-vet.aspx

European Quality Assurance in Vocational Education and Training (n.d.-f). Italy - Standardising internal processes. Retrieved from http://www.eqavet.eu/qc/gns/case-studies/2008-Case-Studies/italy-standardising-internal-processes.aspx

European Quality Assurance in Vocational Education and Training (n.d.-g). Slovenia - A central committee for quality assurance. Retrieved from http://www.eqavet.eu/qc/gns/case-studies/2008-Case-Studies/slovenia-central-committee-forquality-assurance.aspx

European Quality Assurance in Vocational Education and Training (n.d.-h). UK - Developing company based training. Retrieved from http://www.eqavet.eu/qc/gns/case-studies/2008-Case-Studies/uk-developing-company-based-training.aspx

Jamshid, A. N., Mahsa, G. \& Hasan, G. (2014). A suggested evaluation model for employees’ performance IT-based organizations. International Journal of Economy, Management, \& Social Sciences, 3(11), 770-775.

Jankalova, M. (2001). Das EFQM - Modell für Excellence. POSTPOINT 2001: Proceedings of $4^{\text {th }}$ International Conference of Representatives of Postal Administrations, Educators and Researchers in Universities (pp. 163-168). Žilina, Slovakia: University of Žilina.

Joshi, M. (2013). Human resource management [PDF]. Retrieved from http://bookboon.com/en/human-resource-managementebook

Konrad, A. M., Prasad, P., \& Pringle, J. (2006). Handbook of Workplace Diversity. Thousand Oaks: SAGE Publishing.

Mashinchi, S., \& Jahanian, R. (2015). Human resources field performance evaluation in the medical center of hasheminejad based on the EFQM excellence model and presenting appropriate solutions. Journal of Applied Environmental \& Biological Sciences, 5(11), 181-189.

Misiakova, K. \& Strenitzerova, M. (2011). Human resources management in networked enterprise. TRANSCOM 2011: Proceedings of $9^{\text {th }}$ European Conference of Young Research and Scientific Workers (pp. 197-200). Žilina, Slovakia: University of Žilina.

Ponisciakova, O., \& Gogolova, M. (2015). Exploiting the potential and possibilities of conscious human resource management in the process of globalization. Globalization and its socio-economic consequences: Proceedings of $15^{\text {th }}$ International Scientific Conference (pp. 597-603). Rajecke Teplice, Slovakia: University of Zilina.

Reucroft, G., \& Scott, T. (2015). HR 2025: The future of work: Managing people [PDF]. Retrieved from http://bookboon.com/en/hr-2025-the-future-of-work-managing-people-ebook

Samardzija, J., \& Kralj, D. (2010). EFQM excellence model 2010 solid framework for introducing environmental innovation. Proceedings of $9^{\text {th }}$ WSEAS International Conference on Circuits, Systems, Signals (pp. 152-164). Vouliagmeni, Greece: Athens Laboratory of Business Administration.

Senyucel, Z. (2009). Managing the human resource in the $21^{\text {st }}$ century. Frederiksberg, Denmark: Zorlu Senyucel \& Ventus Publishing ApS.

Vartiak, L. (2015). Achieving excellence in projects. Procedia Economics and Finance, 26, 292-299.

Vartiak, L. (2016). An overview of environmental excellence models. Economic \& Environmental Studies, 16(3), 337-347.

Vouzas, F., Gotzamani, K., \& Ispikoudi, K. (2007). Business excellence and human resources: investigating best practices in european quality awarded greek organizations. Proceedings of $12^{\text {th }}$ International Conference on ISO 9000 \& TQM (pp. 16). Taichung City, Taiwan: National Chin-Yi University of Technology. 